KS. RAFAE DAPPA

Wydział Teologiczny Uniwersytetu Śląskiego

\title{
BADANIE PRZEDPROCESOWE W AKTUALNYM PORZĄDKU PRAWNYM
}

Treść: Wstęp. - 1. Dochodzenie wstępne w Kodeksie Prawa Kanonicznego z 1983 r. - 2. Dochodzenie wstępne w Instrukcji Dignitas Connubii z 2005 r. - 3. Dochodzenie przedprocesowe w Mitis Iudex Dominus Iesus z 2015 r. - Podsumowanie.

\section{Wstęp}

Jednym z postulatów Synodu Biskupów na temat rodziny, jaki odbywał się w 2015 roku w Watykanie, było uczynienie bardziej dostępnym dla wiernych procedur związanych z rozpoznaniem nieważności małżeństwa. Ojcowie synodalni, wśród licznych propozycji mających na celu realizację tego zamierzenia, zgłosili projekt utworzenia w diecezjach darmowych punktów konsultacyjnych, w których wierni, poddający w wątpliwość ważność swojego małżeństwa, mogliby uzyskać fachową pomoc i zostać przygotowani do rozpoczęcia procesu sądowego przed kompetentnym trybunałem kościelnym¹ ${ }^{1}$ Postulat ten został skodyfikowany w Liście apostolskim motu proprio Mitis Iudex Dominus Iesus z 15 sierpnia 2015 r., w którym to dokumencie Papież Franciszek, w art. 2 Ratio procedendi, wprowadza nową procedurę dochodzenia przedprocesowego, zwanego również duszpasterskim

\footnotetext{
${ }^{1}$ Por. Instrumentum laboris, XIV Assemblea Generale Ordinaria: La vocazione e la missione della famiglia nella Chiesa e nel mondo contemporaneo, Vaticano 23.06.2015, http://www.vatican.va/roman_curia/synod/documents/rc_synod_doc_20150623_ instrumentum-xiv-assembly_it.html (09.11.2017), n. 114-117.
} 
(investigatio praeiudicialis seu pastoralis). Sama procedura badania przedprocesowego nie jest w prawie kanonicznym niczym nowym. Funkcjonowała już ona wcześniej i to zarówno w normach kodeksowych jak i pozakodeksowych. Warto zauważyć jednak, że nowa regulacja prawna papieża Franciszka nie jest do końca tożsama z tym, co do tej pory w prawie określane było mianem investigatio praevia. Wskazuje na to chociażby inna nomenklatura. Taki stan rzeczy może budzić pewnego rodzaju nieporozumienia i niebezpieczeństwo pomieszania procedur.

Celem niniejszego artykułu jest więc próba, przynajmniej bardzo ogólna, opisania charakteru dochodzenia przedprocesowego zmierzającego do złożenia skargi powodowej o stwierdzenie nieważności małżeństwa oraz próba usystematyzowania tej nowej procedury, w stosunku do funkcjonującej już wcześniej investigatio praevia, o której w can. 1717-1719 CIC oraz w art. 120, \$1 DC. W pierwszej kolejności zostanie przedstawiona kwestia dochodzenia wstępnego, o którym mowa w Kodeksie Prawa Kanonicznego z 1983 roku, następnie analizie zostanie poddana Instrukcja Dignitas connubii z 2005 roku, a jako ostatnia - regulacja prawna papieża Franciszka z 2015 roku. Na zakończenie wszystkie te trzy dokumenty zostaną poddane analizie porównawczej, oczywiście w odniesieniu do poruszanego tematu.

\section{Dochodzenie wstępne w Kodeksie Prawa Kanonicznego z 1983 r.}

Kodeks Prawa Kanonicznego porusza temat dochodzenia wstępnego w księdze VII, części IV, rozdziale I. Zgodnie z normą can. 1717 \$1 CIC:

Quoties Ordinarius notitiam, saltem veri similem, habet de delicto, caute inquirat, per se vel per aliam idoneam personam, circa facta et circumstantias et circa imputabilitatem, nisi haec inquisito omnino superflua videatur ${ }^{2}$.

${ }^{2}$ Codex Iuris Canonici auctoritate Ioannis Pauli PP. II promulgatus, 25.01.1983, AAS 75 (1983), pars II, s. 1-317 [dalej: CIC], can. 1717\$1. 
Umiejscowienie tego kanonu może sugerować czysto procesową naturę dochodzenia wstępnego oraz związanie tej procedury jedynie z procesem karnym. Nie jest to jednak prawdą. Jak słusznie zauważa J. Sanchiz, dochodzenie wstępne to procedura wspólna zarówno dla postępowania sądowego, jak i administracyjnego, mającego na celu wymierzenie lub deklarowanie kary ${ }^{3}$. Analiza can. $1718 \$ 1,3^{\circ}, 1720$ oraz 1721 CIC pokazuje zresztą bardzo wyraźnie, że w następstwie dochodzenia wstępnego ordynariusz może postępować albo na drodze dekretu pozasądowego, albo na drodze procesu karnego ${ }^{4}$.

Ściśle rzecz ujmując dochodzenie wstępne (investigatio praevia) określane jest w literaturze przedmiotu jako procedura poprzedzająca proces, mająca na celu weryfikację warunków wszczęcia postępowania sądowego lub administracyjnego celem wymierzenia lub deklarowania kary, określonych szczegółowo w can. $1341 \mathrm{CIC}^{5}$. Przedmiotem dochodzenia wstępnego - co wynika zresztą wprost z tekstu can. $1717 \$ 1 \mathrm{CIC}$ - są fakty i okoliczności prawdopodobnego czynu przestępczego oraz poczytalność sprawcy. By można było to zbadać, potrzebne jest oczywiście najpierw doniesienie o czynie przestępnym, przynajmniej prawdopodobne. Chodzi więc o przestępstwa, o których w can. 1364-1399 CIC oraz w Motu Proprio Sacramentorum sanctitatis tutela zawierającym Normae de gravioribus delictis z 2010 roku $^{6}$. Prawodawca, w przypadku wpłynięcia przynajmniej prawdopodobnego zgłoszenia o czynie przestępczym, nakłada na

\footnotetext{
${ }^{3}$ Por. J. SANCHIs, L'indagine previa al processo penale (cann. 1717-1719), w: AA.Vv., I procedimenti speciali nel diritto canonico, Studi Giuridici XXVII, Città del Vaticano 1992, s. 248.

${ }^{4}$ Por. can. 1720-1721 CIC.

${ }^{5}$ Por. V. De Paolis, Processo penale, w: Nuovo Dizionario di Diritto Canonico, red. C.C. Salvador, V. De Paolis, G. Ghirlanda, Milano 1996, s. 851;

can. 1341 CIC: "Ordinarius proceduram iudicialem vel administrativam ad poenas irrogandas vel declarandas tunc tantum promovendam curet, cum perspexerit neque fraterna correctione neque correptione neque aliis pastoralis sollicitudinis viis satis posse scandalum reparari, iustitiam restitui, reum emendari».

${ }^{6}$ Normae de delictis Congregationi pro Doctrina Fidei reservatis seu Normae de delictis contra fidem necnon de gravioribus delictis, 21.05.2010, AAS 102 (2010), 419-430.
} 
ordynariusza obowiązek wszczęcia dochodzenia wstępnego, chyba że skąd inąd jest to zupełnie zbędne (np. gdy postępowanie w tej samej sprawie toczyło się już przed sądem cywilnym, a sprawca został uznany winnym).

Dla określenia charakteru dochodzenia wstępnego kwestią równie ważną co przedmiot, jest jego podmiot, a właściwie podmioty, bo norma can. $1717 \$ 1 \mathrm{CIC}$ wskazuje na dwa podmioty odpowiedzialne za przeprowadzenie investigatio praevia. Pierwszym i głównym jest ordynariusz. To on podejmuje najważniejsze decyzje dotyczące wszczęcia i konkluzji procedury, wyboru drogi postępowania, skierowania akt do archiwum itp. Może on również sam, osobiście prowadzić dochodzenie. To on określany jest jako duminus dochodzenia wstępnego ${ }^{7}$. Rodzi się jednak pytanie, jak szeroko należy rozumieć określenie «ordynariusz» w kontekście can. 1717 CIC; czy termin ten obejmuje tylko biskupa diecezjalnego i ordynariuszy w prawie z nim zrównanych, czy też należy przyjąć interpretację szerszą, zgodną z normą can. 134 CIC. W tej kwestii autorzy nie są do końca zgodni. Oczywiście nikt nie podważa kompetencji do przeprowadzenia dochodzenia wstępnego wyższych przełożonych kleryckich instytutów zakonnych na prawie papieskim i kleryckich stowarzyszeń życia apostolskiego na prawie papieskim, ale kwestią sporną jest kompetencja wikariusza generalnego i wikariusza biskupiego. Zdaniem niektórych autorów «ordynariuszami kompetentnymi do podjęcia działania na podstawie kan. $1717 \$ 1$ nie są wszyscy ordynariusze miejscowi, ale tylko ci spośród nich, którym przysługuje biskupia władza zwyczajna własna obejmująca funkcję ustawodawczą, wykonawczą i sądowniczą. Nie posiadają jej więc: wikariusz generalny i wikariusz biskupi, ponieważ na mocy urzędu nie mają władzy sądowniczej» ${ }^{8}$. Zdaniem innych autorów pod pojęciem «ordynariusz» użytym w can. 1717 \$1 CIC

\footnotetext{
${ }^{7}$ Por. J. SANChis, L'indagine previa, s. 242.

${ }^{8}$ J. Krukowski, Proces Karny, w: Komentarz do Kodeksu Prawa Kanonicznego. Księga VII. Procesy, red. J. Krukowski, Poznań 2007, s. 402; por. także A. MizińsKi, Ruolo preminente dell'Ordinario nel processo penale canonico secondo la normativa del CIC del 1983, w: Il processo penale canonico, red. Z. Suchecki, Roma 2003, 131-167.
} 
należy rozumieć nie tylko biskupów diecezjalnych i im w prawie zrównanych, ale również wikariusza generalnego i wikariusza biskupiego, czyli zgodnie z normą ogólną can. 134 CIC. Zarówno wikariusz generalny, jak i wikariusz biskupi są bowiem kompetentni, również w materii karnej, w obszarze zadań im powierzonych. Jeśli przestępstwo zostało popełnione $\mathrm{w}$ ramach ich kompetencji, zobowiązuje ich powinność określona w can. $1717 \$ 1 \mathrm{CIC}^{9}$. Ta interpretacja wydaje się być bardziej słuszna, gdyż odpowiada ona normie ogólnej określającej samo pojęcie «ordynariusz». Ponadto, jak dowodzą materiały z prac przygotowawczych do obowiązującego Kodeks Prawa Kanonicznego, intencją konsultorów było poszerzenie grona odpowiedzialnych za dochodzenie wstępne, chodziło szczególnie o wyższych przełożonych zakonnych, dlatego świadomie użyty został termin «ordynariusz» a nie «biskup diecezjalny» ${ }^{10}$. Przypomnieć w tym miejscu jednak należy, że zgodnie z normą can. 480 CIC ani wikariusz generalny, ani wikariusz biskupi nie powinien działać wbrew woli biskupa diecezjalnego, a wszystkie ważne sprawy powinny mu być referowane ${ }^{11}$.

Drugim podmiotem odpowiedzialnym za investigatio previa jest przeprowadzający to dochodzenie. To osoba, która faktycznie prowadzi instrukcję dochodzenia wstępnego, przesłuchuje, zbiera dowody, itp. Prawodawca kościelny powierza tę funkcję albo samemu ordynariuszowi, albo innej osobie przez niego wyznaczonej, którą wprost nazywa investigator ${ }^{12}$. Investigator (trudno znaleźć polski odpowiednik tego słowa, adekwatny do pełnionej funkcji) działa wtedy na podstawie specjalnego mandatu ordynariusza. Co do jego osoby, Prawodawca kościelny nie stawia żadnych wygórowanych wymagań, norma can. 1717 \$1 CIC określa jedynie, że ma to być osoba odpowiednia (persona idonea). Może to więc być duchowny lub świecki,

\footnotetext{
${ }^{9}$ Por. J. Sanchis, L'indagine previa, s. 242-243.

${ }^{10}$ Por. Communicationes, 12 (1980), s. 189.

${ }^{11}$ Can. 480 CIC: «Vicarius generalis et Vicarius episcopalis de praecipuis negotiis et gerendis et gestis Episcopo dioecesano referre debent, nec umquam contra voluntatem et mentem Episcopi dioecesani agant».

${ }^{12}$ Por. can. $1718 \$ 4$ CIC.
} 
mężczyzna lub kobieta ${ }^{13}$. Kanon nie określa nawet tego, czy osoba ta ma mieć wykształcenie prawnokanoniczne, czy też nie. Jak słusznie zauważają zresztą kanoniści, na etapie dochodzenia wstępnego nie można jeszcze mówić o procesie w sensie ścisłym, ten jeszcze się nie rozpoczął, dlatego też nie jest wymagane, by do jego przeprowadzenia wyznaczany był sędzia ${ }^{14}$. Prawodawca kościelny pozostawia w tym względzie całkowitą wolność ordynariuszowi, z tym jednak zastrzeżeniem, że kto prowadzi dochodzenie wstępne, nie może później, gdy ewentualnie proces zostanie jednak wszczęty, być w nim sędzią ${ }^{15}$. Norma can. $1717 \$ 3$ CIC określa natomiast, że investigator ma takie same uprawnienia i obowiązki jak audytor w procesie ${ }^{16}$. Chcąc więc poznać szczegółowe uprawnienia prowadzącego dochodzenie wstępne, a co z tym jest związane lepiej zrozumieć naturę tego dochodzenia, należy sięgnąć do art. 2, rozdziału I, tytułu II, części I, księgi VII Kodeksu Prawa Kanonicznego, który traktuje o audytorach w ogólności. Do zadań audytora należy więc przede wszystkim zebranie dowodów i przekazanie ich sędziemu. Audytor może również, jeśli co innego nie zostało postanowione, decydować w międzyczasie, jakie dowody i w jaki sposób powinny być zbierane ${ }^{17}$. Odnosząc te uprawnienia do zadań spełnianych przez tego, kto w prawie określany jest mianem investigator podkreślić należy, że:

- investigator posiada co prawda uprawnienia audytora, ale nie jest audytorem w sensie ścisłym;

- charakter prawny aktywności audytora nie jest tożsamy z aktywnością prowadzącego dochodzenie wstępne;

${ }^{13}$ Por. J. SAnCHIs, L’indagine previa, s. 244; por. także: Communicationes, 12 (1980), s. 189; G. Leszczy ́́sKi, Uczestnictwo wiernych świeckich w posłudze zarządzania, nauczania i uświęcania Kościoła, Łódzkie Studia Teologiczne, 2000, 9, s. 330.

${ }^{14}$ Por. V. De Paolis, Processo penale, s. 853.

${ }^{15}$ Por. can. $1717 \$ 3$ CIC; por. także J. OstrowsKI, L’indagine previa nel processo penale giudiziario In riferimento Alla dimissione dallo stato clericale nel Codice di Diritto Canonico di 1983, Studia Prawnoustrojowe 24 (2014), s. 262.

${ }^{16}$ Can. $1717 \$ 3$ CIC: «Qui investigationem agit, easdem habet, quas auditor in processu, potestates et obligationes».

${ }^{17}$ Por. can. $1428 \$ 3$ CIC. 
- w ramach dochodzenia wstępnego to ordynariusz decyduje o tym, co w procesie wobec audytora postanawia sędzia ${ }^{18}$.

Podsumowując, o ile przedmiot dochodzenia wstępnego ściśle wskazuje na charakter procesowy tego postępowania, o tyle podmiot - szczególnie w osobie określanej przez prawo jako investigator - wskazuje raczej na charakter administracyjny. Biorąc również pod uwagę fakt, że dochodzenie wstępne poddane jest wykonawczej władzy rządzenia ordynariusza, komentatorzy prawa opowiadają się za tym, że natura dochodzenia wstępnego, o którym mowa w can. 1717-1719 CIC, jest administracyjna ${ }^{19}$.

\section{Dochodzenie wstępne w Instrukcji Dignitas Connubii z 2005 r.}

Mianem investigatio praevia określana jest również możliwość weryfikacji co do kompetencji trybunału, zdolności procesowej strony powodowej lub meritum sprawy, w przypadku wniesienia skargi powodowej o stwierdzenie nieważności małżeństwa. Możliwość tę szczegółowo określa art. 120 Instrukcji Dignitas Connubii:

$\$ 1$. Praeses potest et debet, si casus ferat, praeviam investigationem instituere quoad quaestionem de competentia tribunalis et de actoris legitima persona standi in iudicio.

$\$ 2$. Quoad meritum vero causae eam tantum instituere potest in ordine ad libellum admittendum vel reiciendum, si libellus videatur quolibet carere fundamento, et quidem tantummodo ad videndum num fieri possit ut aliquod ex processu fundamentum appareat ${ }^{20}$.

Prawodawca pozwala, a w niektórych wypadkach nawet zobowiązuje przewodniczącego trybunału do podjęcia stosownych działań, na zasadzie dochodzenia wstępnego, celem rozstrzygnięcia, czy skargę

\footnotetext{
${ }^{18}$ Por. J. SAnchis, L'indagine previa, s. 246; por. także V. De Paolis, Processo penale, s. 853.

${ }^{19}$ Por. J. SANCHis, L'indagine previa, s. 248-249.

${ }^{20}$ Instructio servanda a tribunalibus dioecesanis et interdioecesanis in pertractandis causis nullitatis matrimonii Dignitas connubii, Città del Vaticano 2005 [dalej: DC], art. 120.
} 
powodową należy przyjąć, czy też ją oddalić. Oczywiście należy w tym miejscu zaznaczyć, że po reformie papieża Franciszka z 2015 r., w obowiązujących dziś procedurach procesowych na etapie przyjmowania skargi powodowej o stwierdzenie nieważności małżeństwa nie mamy jeszcze do czynienia z przewodniczącym trybunału, ten zostaje wyznaczony dopiero w kolejnym kroku procesowym, skarge zaś przyjmuje wikariusz sądowy ${ }^{21}$. Zmienił się więc podmiot dochodzenia wstępnego. Pomimo tej zmiany obowiązywalność samej normy prawnej oraz jej zasadność wydaje się być nadal aktualna.

Co się tyczy przedmiotu dochodzenia wstępnego, to na podstawie normy art. 120 DC można wyznaczyć trzy obszary poszukiwania:

- badanie co do kompetencji sądu;

- badanie co do zdolności procesowej strony powodowej;

- badanie co do meritum sprawy.

Podmiotem działającym (duminus dochodzenia wstępnego) jest więc wikariusz sądowy. To on, działając ex officio, jeszcze przed wezwaniem strony pozwanej, ale już jednak w ramach czynności procesowych może (a czasem nawet powinien) przeprowadzić dochodzenie polegające np. na przesłuchaniu jakiegoś świadka, czy zapoznaniu się z jakimś dokumentem, celem zweryfikowania fumus boni iuris sprawy, co do której ma podjąć decyzję ${ }^{22}$.

Mając powyższe na uwadze nie ma żadnych wątpliwości, że charakter investigatio praevia, o którym w art. 120 DC, jest czysto procesowy. Wskazuje na to zarówno przedmiot, jak i podmiot tego postępowania.

\footnotetext{
${ }^{21}$ Por. Franciszek, List apostolski motu proprio Mitis Iudex Dominus Iesus (tekst łacińsko-polski), Tarnów 2015 [dalej: CIC/MIDI], can. 1676.

${ }^{22}$ Por. W. GóRAlski, Skarga o stwierdzenie nieważności matżeństwa czy prośba o jego unieważnienie? Refleksja kanonistyczno-duszpasterska na kanwie introductio causa, Ius Matrimoniale 25(2014), nr 3, s. 84.
} 


\section{Dochodzenie przedprocesowe w Mitis Iudex Dominus Iesus z 2015 r.}

Papież Franciszek w Liście apostolskim Mitis Iudex Dominus Iesus, w art. 2-5 Ratio procedendi, wprowadza całkiem nową procedurę dochodzenia przedprocesowego, czyli duszpasterskiego (investigatio praeiudicialis seu pastoralis). Już sama nazwa tego postępowania sugeruje, że różni się ono od omawianego wyżej investigatio praevia. Aby ukazać, na czym polega ta różnica, podobnie jak w przypadku wyżej omówionych procedur, należy najpierw określić przedmiot, podmiot i charakter tego postępowania.

Zgodnie z normą art. 2 Ratio procedendi CIC/MIDI:

Investigatio praeiudicialis seu pastoralis, quae in structuris paroecialibus vel dioecesanis recipit christifideles separatos vel divortio digressos de validitate sui matrimonii dubitantes vel de nullitate eiusdem persuasos, in eum finem vergit ut eorum condicio cognoscatur et colligantur elementa utilia ad processum iudicialem, ordinarium an breviorem, forte celebrandum. Quae investigatio intra pastorale opus dioecesanum de matrimonio unitarium evolvetur ${ }^{23}$.

Celem dochodzenia przedprocesowego jest «uzyskanie informacji, które mogą być pomocne w procesie sądowym o stwierdzenie nieważności małżeństwa, niezależnie od formy tego procesu» ${ }^{24}$. Efektem, a właściwie punktem dojścia jest zaś sporządzenie skargi powodowej, o ile istnieją ku temu przesłanki $\mathrm{i}^{25}$. Przedmiot investigatio praeiudicialis seu pastoralis wyznaczany został przez Prawodawcę w następujących zakresach tematycznych:

\footnotetext{
${ }^{23}$ Art. 2 Ratio procedendi CIC/MIDI.

${ }^{24}$ P. Kroczen, Komentarz do art. 2 Ratio procedendi, w: Praktyczny komentarz do Listu apostolskiego motu proprio Mitis Iudex Dominus Iesus papieża Franciszka, red. P. Skonieczny, Tarnów 2015, s. 44.

${ }^{25}$ Art. 5 Ratio procedendi CIC/MIDI: « Omnibus elementis collectis, investigatio perficitur libello, si casus ferat, tribunali competenti exhibendo».
} 
- $\quad$ sytuacja przed zawarciem małżeństwa;

- okoliczności zawarcia małżeństwa;

- $\quad$ sytuacja, w której obecnie znajduje się małżonek ${ }^{26}$.

Co się zaś tyczy podmiotu działającego, to został on wyznaczony w obszarze szeroko rozumianego jednolitego diecezjalnego duszpasterstwa małżeństw. Art. 3 Ratio procedenti precyzuje zaś, że dochodzenie to powinno zostać powierzone osobom uznanym za odpowiednie (persona idonea) przez ordynariusza miejsca, posiadającym odpowiednie kompetencje, choć niekoniecznie prawnokanoniczne. To nie ordynariusz jest jednak dominus tego dochodzenia, ale ta konkretna, wyznaczona przez niego osoba. Jako przykład osób odpowiedzialnych za investigatio praeiudicialis seu pastoralis Prawodawca wymienia: proboszcza; osobę, która przygotowywała nupturientów do małżeństwa; innych duchownych, osoby konsekrowane oraz świeckich zatwierdzonych przez ordynariusza miejsca ${ }^{27}$. Jak można dostrzec, wachlarz możliwości jest w tym wypadku bardzo szeroki, co rodzi uzasadnione wątpliwości dotyczące kompetencji tychże osób. Komentatorzy wskazują co prawda na możliwość zastosowania zatwierdzenia $\mathrm{w}$ formie nihil obstat, mandatum, czy też missio canonica, ale sama norma prawna tak szczegółowych uregulowań już nie wprowadza ${ }^{28}$. Pozostaje więc pytanie, jakie kryterium powinien przyjąć ordynariusz miejsca dla uznania tych osób za odpowiednie, skoro żadnych konkretnych kompetencji Prawodawca nie przewidział. Co więcej, norma prawna wprost neguje konieczność posiadania kompetencji prawnokanonicznych, a te przecież są

\footnotetext{
${ }^{26}$ Por. P. Krocze , Komentarz do art. 2 Ratio procedendi, s. 44.

${ }^{27}$ Art. 3 Ratio procedendi CIC/MIDI: «Eadem investigatio personis concredetur ab Ordinario loci idoneis habitis, competentiis licet non exclusive iuridico-canonicis pollentibus. Inter eas habentur in primis parochus proprius vel is qui coniuges ad nuptiarum celebrationem praeparavit. Munus hoc consulendi committi potest etiam aliis clericis, consecratis vel laicis ab Ordinario loci probatis».

${ }^{28}$ Por. P. Kroczeк, Komentarz do art. 3 Ratio procedendi, s. 46.
} 
potrzebne osobom konsultującym i pomagającym w sporządzeniu skargi powodowej ${ }^{29}$.

Sama nazwa investigatio praeiudicialis seu pastoralis, ze względu na łacińską partykułę «seu», może sugerować tożsamość pastoralnego charakteru tego dochodzenia $\mathrm{z}$ charakterem procesowym, albo przynajmniej przedprocesowym ${ }^{30}$. Tak jednak nie jest. Biorąc pod uwage przedmiot i podmiot dochodzenia przedprocesowego, o którym w art. 2-5 Ratio procedendi CIC/MIDI, stwierdzić należy, że jego natura jest pozasądowa, a charakter pastoralny. Investigatio praeiudicialis seu pastoralis nie jest częścią procesu małżeńskiego, a strony nie są zobligowane do przestrzegania tej procedury. Jest to dochodzenie fakultatywne, które nie musi wywierać żadnych konsekwencji prawnych ${ }^{31}$.

$\mathrm{Na}$ marginesie uwag o investigatio praeiudicialis seu pastoralis wspomnieć jeszcze należy o innej procedurze przewidzianej w MIDI. Art. 15 Ratio procedendi zobowiązuje bowiem wikariusza sądowego do zatroszczenia się o uzupełnienie skargi powodowej, która została co prawda złożona celem rozpatrzenia jej w trybie procesu zwykłego, jeśli jego zdaniem ta mogłaby być rozpatrywana na drodze procesu skróconego ${ }^{32}$. Wydaje się więc oczywiste, że wikariusz sądowy, dla podjęcia takiej decyzji musi przeprowadzić cośw rodzaju investigatio praevia odnośnie do meritum sprawy, choć norma prawna wprost

\footnotetext{
${ }^{29}$ Por. U. Nowicka, Proces o nieważność małżeństwa po Mitis Iudex Dominus Iesus w pytaniach i odpowiedziach, Warszawa 2016, s. 22.

${ }^{30}$ Por. F. BARbaro, La investigatión preliminar en las nuevas normas procesales del M.P. Mitis Iudex Dominus Iesus, Anuario de derecho cacónico 51(2016), s. 41.

${ }^{31}$ Por. tamże, s. 43.

${ }^{32}$ Art. 15 Ratio procedendi CIC/MIDI: «Si libellus ad processum ordinarium introducendum exhibitus sit, at Vicarius iudicialis censuerit causam processu breviore pertractari posse, in notificando libello ad normam can. $1676 \S 1$, idem partem conventam quae eum non subscripserit invitet, ut tribunali notum faciat num ad petitionem exhibitam accedere et processui interesse intendat. Idem, quoties oporteat, partem vel partes quae libellum subscripserint invitet ad libellum quam primum complendum ad normam can. 1684 ».
} 
tego tak nie nazywa. Rozeznanie to byłoby zbieżne z tym, o czym mówi art. 120 DC.

\section{Podsumowanie}

Podstawowy wniosek wynikający z powyższej analizy jest taki, że pomimo pozornego podobieństwa żadna $\mathrm{z}$ trzech przedstawionych w niniejszym przedłożeniu procedur nie jest tożsama $\mathrm{z}$ jakąkolwiek inną, wszystkie różnią się między sobą i nie można ich ani utożsamiać, ani mylić. Investigatio praevia, o którym w can. 1717-1719 CIC ma charakter administracyjny. Nie jest częścią procesu, a jedynie przygotowuje postępowanie procesowe i pomaga w podjęciu decyzji, jaką drogę postępowania ordynariusz powinien wybrać. Investigatio praevia, o którym w art. 120 DC ma charakter procesowy i jest integralną częścią procesu o stwierdzenie nieważności małżeństwa. Investigatio praeiudicialis seu pastoralis, o którym w art. 2 Ratio procedendi CIC/MIDI jest procedurą o charakterze pastoralnym i nie ma żadnego faktycznego przełożenia procesowego. Jedynie skarga powodowa, która może być sporządzona na zakończanie tego postępowania jest łącznikiem pomiędzy tą procedurą a procesem małżeńskim. Podstawowa różnica pomiędzy tymi procedurami dotyczy podmiotu działającego. Jedynie w investigatio praevia, o którym w art. 120 DC podmiotem działającym jest sędzia, a właściwie wikariusz sądowy. Posiada on urząd i władzę z tym urzędem związaną. W pozostałych dwóch procedurach brak wymogu wykształcenia prawnokanonicznego osób odpowiedzialnych za ich przeprowadzenie. O ile w przypadku investigatio previa, o którym w can. 1717-1719 CIC dominus tego postępowania ma jeszcze władzę rządzenia, ale już przeprowadzający je - nie koniecznie, o tyle w nowej procedurze, o której w CIC/MIDI, nawet dominus investigatio praeiudicialis seu pastoralis nie musi mieć władzy rządzenia.

Mając powyższe na uwadze stwierdzić należy, że investigatio praeiudicialis seu pastoralis, $\mathrm{w}$ relacji do investigatio praevia ma o wiele mniejsze znaczenie prawne. Można mieć również wątpliwości co do praktycznej potrzeby wprowadzania tej procedury, tym bardziej, że już Instrukcja Dignitas connubii zobowiązywała do utworzenia przy 
każdym sądzie punktów konsultacyjnych, służących pomocą w rozpoczęciu procesu małżeńskiego ${ }^{33}$. Punkty te funkcjonują i spełniają swoją rolę.

Pomimo tych wątpliwości warto w przyszłości szczegółowo opisać recepcję art. 2-5 Ratio procedendi CIC/MIDI. W tym celu należałoby zastanowić się nad konkretnymi rozwiązaniami praktycznymi i porównać je, mając na uwadze nie tylko teren naszej Konferencji Episkopatu, ale także innych krajów.

\section{The pre-judicial inquiry in accordance with the applicable legal norms}

Apostolic Letter Motu Proprio of Pope Francis, Mitis Iudex Dominus Iesus, institutes in art. 2 Ratio procedendi, a new procedure for the pre-judicial also called pastoral inquiry. It should take place "in diocesan and parish structures for separated or divorced faithful who have doubts regarding the validity of their marriage or are convinced of its nullity". It should also lead to getting know the situation of those persons and gathering all useful for the possible judicial course information.

It seems that a legislator completely consciously calls the procedure investigatio praeiudicialis in contrast to investigatio praevia presented in can. 1717 - 1719 CIC and in DC, art. 120, \$1. They are different according to both, the nature and proceeding and it is not possible to mix or substitute them.

Following submission will constitute a comparative analysis of investigatio praeiudicialis included in art. 2 Ratio procedendi CIC/MIDI; investigatio praevia included in art. $120, \$ 1 \mathrm{DC}$ as well as investigatio praevia included in can. 1717-1719 CIC.

SŁOWA KLUCZOWE: investigatio praevia; investigatio praeiudicialis; dochodzenie duszpasterskie

KEY WORDS: investigatio praevia; investigatio praeiudicialis; pastoral inquiry

\footnotetext{
${ }^{33}$ Por. art. $113 \$ 1$ DC.
} 


\section{Nota o Autorze:}

Ks. DR RAfal DAPPa - adiunkt w Katedrze Prawa Kanonicznego i Ekumenizmu na Wydziale Teologicznym Uniwersytetu Śląskiego w Katowicach, Pomocniczy Wikariusz Sądowy Sądu Biskupiego w Gliwicach, Delegat Biskupa ds. Ochrony dzieci i Młodzieży w Diecezji Gliwickiej. 